This is an even-handed account of Mee which takes care to situate him in the milieu of his time and place. He was a eugenicist and an imperialist, who viewed the British Empire as a force for universal good, but he was also a practicing Christian and idealist who strove for a world where children would be offered equal opportunities and where poverty would be eradicated. Above all, he was a proud Englishman. But, all of this does not add up to sufficient reason for Crawford to devote time to writing a biography; or, for that matter, for others to read it. Mee warrants a biography because he was a cultural tour de force. He was a prolific writer and editor who produced popular publications intended for child readers that reflected the values and standards of the period and place. Contemporary Canadian readers may not be familiar with the man or the publications, but this biography provides fascinating insights into the ideals of middle-class Edwardian England through the writings of a man whose life epitomized those ideals and whose work had an impact on several generations of children.

Penney Clark

University of British Columbia

\title{
Pamela Grundy \\ Color and Character: West Charlotte High and the American Struggle over Educational Equality
}

Chapel Hill: University of North Carolina Press, 2017. 236 pp.

With the exception of a few broad synthetic works, much of what historians know about school desegregation comes from case studies of individual school districts-usually cities, sometimes rural or suburban districts. Some scholars have zoomed in even closer, on a single school. Vanessa Siddle Walker's Their Highest Potential (1994) was the most influential in taking this approach, opening up the strong educational traditions of one school during segregation and thus shifting the questions we ask about what desegregation meant. Pamela Grundy's Color and Character shares that singleschool focus, and the commitment to understand desegregation in its longer historical trajectory - as a moment poised between long decades of segregation and the present reality of resegregation in many US school systems.

Grundy describes a "dramatic story of triumph and struggle" (51) at Charlotte, North Carolina's West Charlotte High School, and then traces both of those realities over time. The school opened in 1938 as a segregated black institution built for African Americans moving to new suburban homes nearby. A class-diverse population of students benefited from highly skilled and committed teaching staff and strong school leadership in the decades before the US Supreme Court's 1954 Brown v. Board of Education decision and the end of legal school segregation. The city's initial desegregation efforts in the late 1950s did not reach West Charlotte, and as directaction civil rights protests began, students felt themselves pulled into the effort, but 
felt their school to be a black "refuge" (51) in an exciting but uncertain time.

The second phase of school desegregation, however, altered West Charlotte fundamentally. Beginning in 1971, many black residents of the school zone who had assumed their children would attend received new assignments instead, while white students now rode buses in to the school. In keeping with the court-ordered desegregation plan that would ultimately win US Supreme Court approval in the 1971 Swann v. Charlotte-Mecklenburg Board of Education decision, West Charlotte now sought and maintained a white majority in both its students and faculty.

Where many cities and school systems resisted busing for desegregation through means violent and loud or stealthy and quiet, Charlotte embraced the project as a part of its shiny boosterish ethos. West Charlotte was the flagship, a "beacon of desegregated achievement" (136). The school managed not only to transition from a historically segregated black institution to a majority-white desegregated one (a transition often quickly undermined elsewhere by white peoples' resistance to sending their children to historically black institutions and neighbourhoods), but to do so while continuing to reflect the strong African American educational tradition and history there.

Things began to change in the late 1980s when the school suffered leadership transitions and was unable to sustain the strong core of black faculty it had previously. Student outcomes flagged and fewer white students and fewer middle-class students attended. A desegregation flagship became a common exemplar of turn-ofthe-century resegregation.

Color and Character offers a fine-grained depiction of life at West Charlotte, especially for the 1950s, 60s, and 70s, by drawing on over eighty oral history interviews conducted by Grundy and her students in cooperation with the University of North Carolina's Southern Oral History Project. Rooted in oral history and focused on West Charlotte, the book finds its distinct place in the robust literature on Charlotte and desegregation. Davidson Douglas and Frye Gaillard traced the many intricacies of the legal efforts around Swann and busing; Matthew Lassiter examined white suburban homeowner politics for resistance as well as supportive cross-class alliances; and Steven Samuel Smith looked at boosters' embrace of desegregation and district-level outcomes. None of these works makes African American experiences of schooling the central focus, as Grundy does by respecting the periodization of that experience, rather than focusing on timelines dictated by court order or economic boosterism.

Grundy works skillfully with the oral history material, giving her narrators' voices ample space in the text. Their poignant, detailed, and at times trenchant characterizations of their school and its meaning in their lives come through clearly. She also moves deftly from close-in details of West Charlotte's story to the city - and at times state and national - context in which it unfolds. She presents decisions made elsewhere that shaped and constrained life at the school. Perhaps the highly local focus makes it easier to chronicle, and to do so richly, than to offer causal analysis. West Charlotte's fate, as a desegregated school as well as a resegregated one, depended on its position in relationship to the broader city. Fewer white students at West Charlotte meant more somewhere else, for example. I would have welcomed more 
attention - even if it meant zooming out from the school more frequently — to why these decisions were made, to more fully understand why as well as how the school changed as it did.

Grundy identifies as a desegregation advocate. She came to the story of West Charlotte seeking to capture the school's special magic in the 1970s and 80s. She offers many compelling points of evidence for how students learned from desegregated educational spaces - as well as of the work involved in building and sustaining these spaces. The segregation inside the school along academic tracks, or the persistent worry that, as one black parent put it, via desegregation "our people" would "be consumed by the white people" (55), reflect harder realities of the process of desegregation and perhaps could offer sources of insight for why the period of desegregated success proved short-lived. Grundy clearly acknowledges these difficulties and inequalities in the process of desegregation, but could plumb their origins and consequences to a greater extent. New approaches to desegregation today-those imagining explicitly anti-racist desegregation - have to face this complex history. One West Charlotte alumnus's view of desegregation in the 1970s has lessons for the present: "Our society is very witty." He continued, "and as new demands come upon us for changing we find new ways to entrench ourselves in the old" (114).

Ansley T. Erickson

Teachers College, Columbia University

Rivka Feldhay and F. Jamil Ragep, eds.

Before Copernicus: The Cultures and Contexts of Scientific Learning in the Fifteenth Century

Montreal \& Kingston: McGill-Queen's University Press, 2016. 344 pp.

Much ink has been spilled on the question of why Nicolaus Copernicus made the radical decision to propose a heliocentric cosmology. Recently, scholarly discussion and debate has centred on potential paths of transmission of Islamic astronomical models that appear in Copernicus's 1543 masterwork De revolutionibus orbium coelestium and his earlier Commentariolus. Beyond Copernicus aims to make this discussion available to a broader historical audience, but also to definitively expose the absurdity of holding the position for the independent European development of these astronomical models in the face of overwhelming evidence - contextual, textual, visual, etc. - of Islamic influence. This evidence illustrates "transformations in the background to the Copernican system" (8) that deal with the body of astronomical and cosmological knowledge, the status of astronomy as a discipline, and the transmission of knowledge. The outcome of these transformations shows that Copernicus's proposal of a sun-centred cosmos was the culmination of a centuries-long Islamic astronomical tradition ( hay'a) that sought to provide physically viable configurations of the cosmos that accounted for celestial motion. 